\title{
0 olho sensível: (est)éticas do visível e políticas de visibilidade
}

\section{Rose Melo Rocha \& Susan Liesenberg}

\section{Resumo}

Analisando 0 circuito de midiatização e energização que gravitou em torno do consumo da imagem de Alan Kurdi, criança síria morta em 2015 durante tentativa frustrada de imigração, problematiza-se a "partilha do sensível" e as implicações éticas deste tipo de visibilidade. Tomando a crítica do visível como método de indagação, defende-se que é paradoxal e ambivalente 0 resultado deste tipo de exposição midiática. 0 consumo e a profanação da imagem da vítima, em que pese seu inegável potencial de denúncia, podem também contribuir para um ciclo de sensibilização midiático que imobiliza seus receptores, a eles oferecendo "pílulas de indignação". Concluímos, ainda, com uma pergunta: a dimensão pedagógica do consumo de imagens não poderia implicar uma política da estética (e das sensibilidades) menos imediatista e individualista?

\section{Palavras-Chave}

Políticas de visibilidade. Ética do visível.

Partilha do sensível. Alan Kurdi. Consumo midiático.

Rose Melo Rocha I rrocha@espm.br

Doutora em Ciências da Comunicação pela ECA/USP com pósdoutorado em Ciências Sociais/Antropologia na PUCSP. Bolsista Produtividade em pesquisa CNPq, lidera o grupo de pesquisa JUVENÁLIA. Pesquisadora vinculada ao PPGCOM/ESPM - Escola Superior de Propaganda e Marketing - SP, Brasil.

Susan Liesenberg | sliesenberg@yahoo.com.br Doutoranda (bolsista CAPES/PROSUP) em Comunicação e Práticas de Consumo pelo PPGCOM/ESPM - Escola Superior de Propaganda e Marketing - SP, Brasil. Mestre em Comunicação e Informação pela Universidade Federal do Rio Grande do Sul (UFRGS)

\section{0 caso Alan: circuitos \\ de midiatização de um visível que choca}

Estar informados nos da nuestra dosis diaria de indignación. La indignación, esa cómoda sensación que nos libera de toda responsabilidad de pensar y de entender. Luis Carlos Valenzuela

No dia 02 de setembro de 2015, uma quartafeira, a foto de Alan Kurdi ${ }^{1}$ ganhou a atenção do mundo. A imagem que o retratara, tornando-0 "peça visual" acessível aos olhos planetários, não era de qualquer ordem. 0 que nos foi dado a ver contemplava a representação imagética de seu cadáver, ele, menino de três anos que jazia à beira-mar, seu frágil corpo de criança, vestido com esmero, involuntariamente imortalizado em sua trágica condição de morte. Corpo infantil vitimado por afogamento, caído inerte, solitário e de bruços entre as águas e as areias do balneário de Bodrum, no litoral turco. Do abandono original ao momento em que 0 registro se disseminou pela primeira vez, uma espiral delirante de reprodutibilidade e sensibilização midiatizada seria disparada. 
A comoção unia-se à forte sensação de impotência ante 0 visto. $\mathrm{Ou}$, antes, a partilha da imagem denunciava uma anterioridade que chocava. $\mathrm{E}$ isto não se deu por acaso. Como tão precisamente escreve Ana Rodríguez (2004),

a politicidade da imagem não reside no social que ela visibilizaria, uma vez que o social seria uma dimensão de toda imagem, mas sim na pergunta sobre 0 olhar escrito nos rastros de um texto que sem ser necessariamente visual fale do não-visto (RODRíGUEZ, 2004, p.93; tradução nossa).

Saberíamos depois que a criança fazia parte de um grupo de refugiados saídos de Kobane, no Norte da Síria, onde viviam. Junto do pai, da mãe e do irmão mais velho, fugiam da guerra em seu país com destino à ilha de Kos, na Grécia. Divididos em dois botes lotados, naufragaram na costa turca. Pela história e impacto da imagem - sucedida ainda por uma sequência de outras fotografias do resgate de seu corpo, em uma delas, sendo tomado nos braços e recolhido por um guarda costeiro -, a "foto chocante de menino morto vira símbolo da crise migratória”" Da família que compunha a onda humana movimentada pelo globo em busca de refúgio, apenas o pai sobreviveu ao naufrágio. Abdullah Kurdi, pai de Alan, diria que, no momento do naufrágio, seus filhos lhe escorreram pelas mãos.

E exatamente o que nos escorre pelas mãos quando consumimos as imagens de Alan? Ante o clamor do visível, arrebatados, seríamos capazes do deslocamento necessário para nos sentirmos parte de um "nós" inclusivo, que acolhe, mas não apaga, a diferença? Ante a alteridade do cadáver, seríamos capazes de qual ordem de comovimento? Nilüfer Demir ${ }^{3}$, fotógrafa de uma agência de notícias turca que cobre há 15 anos a crise migratória na região onde Alan foi encontrado morto, declarou em entrevista ter ficado "petrificada" ao ver o corpo do menino, caído a 100 metros distante do corpo de seu irmão mais velho, Galip:

Ele estava deitado de barriga para baixo sem vida na areia, de camiseta vermelha e com seu short azul escuro. A única coisa que eu poderia fazer era tornar seu clamor ouvido. Naquele momento, eu pensei que poderia fazer isso ao acionar minha câmera e fazer sua foto [...] Essa imagem mostra 0 quão dramático 0 incidente foi. [...] Eu testemunhei muitos incidentes com imigrantes nesta região, suas mortes, seus dramas. Espero que isso agora mude. Fiquei cho-

As primeiras notícias sobre a morte da criança traziam o seu nome grafado como Aylan. Ao longo da cobertura jornalística sobre 0 fato, uma tia do menino declarou em entrevista que a grafia correta era Alan. Por ter ficado mundialmente conhecido pela primeira grafia utilizada (Aylan), a maioria dos veículos informativos optou por mantê-la. Nós aqui optamos por chamá-lo de Alan.

2 Disponível em http://g1.globo.com/mundo/noticia/2015/09/foto-chocante-de-menino-morto-vira-simbolo-da-crise-migratoriaeuropeia.html (Acesso em 26/10/2015).

3 Nilüfer virou celebridade internacional instantânea ao ser reconhecida como a fotógrafa do garotinho Alan. Um verbete na enciclopédia coletiva Wikipedia foi criado com o seu nome e biografia após a celebridade da foto. Disponível em https:// en.wikipedia.org/wiki/Nil\%C3\%BCfer_Demir (Acesso em 26/10/2015).

Disponível em http://g1.globo.com/mundo/noticia/2015/09/fiquei-petrificada-diz-fotografa-que-fez-imagem-de-menino-siriomorto.html (Acesso em 26/10/2015). 
cada, me senti mal por eles. A melhor coisa a fazer era tornar sua tragédia conhecida ${ }^{4}$.

Mobilizadas tanto pelo impacto da disseminação desta imagem quanto por tudo aquilo que ali já não estava retratado, interessa-nos em nosso artigo proceder a uma aproximação bastante peculiar da temática que articula este dossiê. Assim, a abordagem que é proposta, ao investigar articulações possíveis entre estética e política, retoma o debate sobre uma ética possível para as visualidades (ROCHA, 2010), considerando a energização implicada na produção e no consumo de narrativas midiáticas (LIESENBERG, 2015). Nosso olhar, visão feita indagação (CARDOSO, 1993), volta-se a este duplo pilar para dali abordar não apenas as políticas de subjetividade, mas, muito fortemente, para debater as políticas possíveis para as sensibilidades.

Retomando Baruch de Spinoza (2008) - nosso fiel da balança de uma ética possível a reger os afetos que estabelecemos com imagens dotadas de visibilidade "sensacional" -, gostaríamos de indagar sobre os regimes de vinculação estabelecidos com a representação de Alan. Teórico dos afetos e das afecções, Spinoza entende que "[0] corpo humano pode ser afetado de muitas maneiras, pelas quais sua potência de agir é aumentada ou diminuída, enquanto outras tantas não tornam sua potência de agir nem maior nem menor" (SPINOZA, 2008, p.163).

Se Spinoza entende ética como aquilo que aumenta nossa potência de agir, se, complementarmente, a estética possa se associar ao aumento de nossa potência de sentir, cabenos uma primeira ordem de questionamento. Referimo-nos à dimensão em essência política do que nos é dado a ver, através da profusão de imagens visuais, e, o que particularmente interessa ressaltar, leva-nos a indagar quais delas, ao nos afetarem, efetivamente aumentam nossa competência corpóreo-cognitiva de ação, ou seja, nossa consciência e nossa prática de intervir.

Pensadores como Fredric Jameson (1995) não sugerem abordagens propriamente positivas do arrebatamento do visível característico das transformações da imagem na pós-modernidade. Para Jameson, o visual, como meio em si de sedução e interpelação, chega a nossos dias a uma situação limítrofe, na qual "a reflexividade como tal se submerge na pura superabundância de imagens como em um novo elemento no qual respiramos como se fosse natural" (JAMESON, 1995, p.120).

Dialogando com esta perspectiva - o circuito narrativo midiático como supermercado de emoções -, Omar Rincón (2006) abre-nos uma brecha significativa, localizando o potencial de ação simbólica dos meios de comunicação "na competência para produzir vínculos e conexão entre os seres humanos" (RINCÓN, 2006, p.99; tradução nossa). Ainda segundo o autor, o "poder de interpelação (comunicar, chamar a atenção, ter impacto) que tem a narração se encontra à medida que propõe uma relação emocional 
e compreensível no fato de contar histórias" (RINCÓN, 2006, p.97; tradução nossa).

Entendemos que o circuito midiático (estético e político) que foi desencadeado pela disseminação da imagem de Alan Kurdi é exemplar de uma "partilha do sensível" (RANCIÈRE, 2009) que confronta e problematiza a promoção ininterrupta de visualidades tão cara às nossas sociedades midiáticas, discursivas e audiovisuais, nas quais, inúmeras vezes, desconhecem-se - seja no plano da produção noticiosa, seja no âmbito do consumo midiático propriamente dito - as implicações políticas profundas do que e do como se é dado a ver fenômenos, casos ou acontecimentos que vêm a público, ganhando o status de "espetaculares".

A visualidade excessiva e a invisibilidade compulsória talvez, de fato, sejam alguns dos braços mais evidentes do debate ético contemporâneo, este que, em nossa acepção, é um caso de imagem, e de políticas e estéticas de visibilidade. A partir da data original em que seu corpo é localizado e transformado em imagem, a vida e morte do pequeno sírio serão publicizadas, compartilhadas e comentadas ininterrupta e ostensivamente pelos diversos canais de comunicação encadeados (PRIMO, 2008) - da imprensa ${ }^{5}$ às redes sociais digitais -, e se tornam onipresentes na cena midiática e no debate cotidiano que compõem as narrativas sobre a crise migratória.
Esta profusão de mobilizações individuais e coletivas na rede caracterizou o que aqui se entende como uma energização, conceito cujo sentido atravessa a metáfora do sistema de produção de energia, tal como classicamente o conhecemos (elétrica, nuclear, eólica, a gás, etc). Virilio (1993, p.76) concebe uma "energética" configurada pela corrente de fluxos movimentada pelas novas tecnologias de comunicação digital (suas redes, bancos de dados e terminais informáticos), na qual a informação transmitida expressa um modo de formação que afeta os meios de organização social em uma corrente de transformação descontínua, alternativa, de curtíssima duração e potente alcance.

Castells (2003) igualmente postula que a tecnologia da informação tornou-se hoje 0 que a eletricidade foi na Era Industrial. Em nossa época, a Internet poderia ser "equiparada tanto a uma rede elétrica quanto ao motor elétrico, em razão de sua capacidade de distribuir a força da informação por todo o domínio da atividade humana" (CASTELLS, 2003, p.7), configurando "redes de informação energizadas pela Internet" (CASTELLS, 2003, p.7), motor de fluxo ativado pelas postagens, conversações e compartilhamentos, assim como ocorreu no caso da representação fotográfica de Alan e de todo o debate social que sucedeu a exposição, reprodução e apropriação de sua imagem. 
A morte de Alan provocou reações da chefia de países da União Europeia. Em seguida à repercussão popular mundial, França e Alemanha assinaram um documento conjunto pedindo a revisão das regras impostas pela União Europeia sobre a garantia de asilo e pediram uma distribuição "justa" de imigrantes nos países do bloco. Pelo Twitter, o primeiroministro da França, Manuel Valls, afirmou que a morte do menino sírio indicava a necessidade de ação urgente para a crise migratória na Europa. "Ele tinha um nome: Aylan Kurdi. Urgência de ação. Urgência de uma mobilização europeia", escreveu Valls no microblog. Após a mensagem, a presidência da França anunciou uma reunião de emergência com os ministros de pastas relacionadas à questão de imigração para discutir medidas em nível nacional e europeu.

0 circuito da imprensa mundial expôs os seus embates éticos internos ${ }^{6}$ sobre publicar ou não as imagens da criança morta, em especial a foto chocante em que aparece de bruços. Em diversos portais de notícias, a imagem era tratada com avisos de prudência antes do acesso às galerias de fotos onde estavam expostas. "AVISO: A IMAGEM
É FORTE"', dizia uma dessas advertências, redigida na forma clássica das letras garrafais das manchetes. Em outra plataforma jornalística, a abertura da galeria de fotos era igualmente precedida por um alerta em caixa alta: "ATENÇÃO: AS IMAGENS A SEGUIR SÃO AGRESSIVAS"•. Seguindo nesta linha, o jornal inglês The Guardian, um dos primeiros a veicular as imagens, também advertia 0 leitor sobre o conteúdo "aflitivo", "angustiante" que tais fotografias comportavam: "Warning: this article contains images that readers may find distressing"9. Por decidir noticiá-las, o Guardian publicou um extenso editorial para justificar as razões de sua escolha ${ }^{10}$, apoiado principalmente no argumento de pretender fazer 0 leitor refletir sobre a gravidade da história de Alan, não podendo, portanto, como veículo de imprensa, sonegar à audiência esta informação/imagem, com a qual buscaria contribuir para despertar a conscientização para a crise migratória na Europa, ainda que reconhecesse poder ser reprovado pelos seus leitores por tomar tal decisão.

0 diário britânico The Independent justificou a sua decisão argumentando que a publicação de

Disponível em http://portalimprensa.com.br/noticias/brasil/74164/divulgacao+da+imagem+de+menino+sirio+morto+na+turquia +divide+opinioes+na+imprensa (Acesso em 26/10/2015).

7 Disponível em http://g1.globo.com/mundo/noticia/2015/09/foto-chocante-de-menino-morto-vira-simbolo-da-crise-migratoriaeuropeia.html (Acesso em 26/10/2015).

8 Disponível em http://www1.folha.uol.com.br/mundo/2015/09/1677028-foto-de-menino-refugiado-morto-na-praia-atrai-atencaopara-crise.shtml (Acesso em 26/10/2015).

9 Disponível em http://www.theguardian.com/world/2015/sep/02/shocking-image-of-drowned-syrian-boy-shows-tragic-plight-ofrefugees (Acesso em 26/10/2015).

10 Disponível em http://www.theguardian.com/commentisfree/2015/sep/07/guardian-decision-to-publish-shocking-photos-ofaylan-kurdi. (Acesso em 26/10/2015). 
uma imagem tão poderosa como a de uma criança morta em tal circunstância poderia mudar a postura da Europa com relação aos refugiados. 0 norte-americano Washington Post classificou a foto como um dos mais trágicos símbolos da crise de refugiados do Mediterrâneo, daí a importância de veiculá-la. 0 The New York Times optou por publicar apenas as imagens em que 0 corpo de Alan aparece já recolhido pelo guarda costeiro e disponibilizou um link que conduzia a uma galeria com montagens artísticas e memes ${ }^{11}$ produzidos pelo mundo afora, feitos em homenagem ao menino e agrupadas pelo site BuzzFeed ${ }^{12}$.

Juntamente com as discussões editoriais sobre a decisão de publicar ou não as imagens, expostas não somente pela própria imprensa ao noticiar 0 fato, mas também levantadas em questionamentos feitos pelos leitores destes veículos e pelas audiências tantas das redes sociais digitais, a imprensa mostrava-se tocada por um fato que "causou consternação" ${ }^{13}$ no mundo, a partir de "fotos de partir o coração" - "heart-rending photos ${ }^{14}$-, como noticiou a rede Aljazeera, argumentando que "se essas imagens não mudarem a Europa, o que irá?" ("If these images don't change Europe, what will?").

\section{Representação, efusão e vinculações possíveis: co-mover ou introverter?}

Enquanto ocorriam as discussões editoriais dos veículos jornalísticos sobre a publicação de imagem, nas redes digitais as fotografias de Alan morto já eram ostensivamente presentes, compartilhadas em vertiginosa profusão. Uma das grandes movimentações de fluxos e conversações que energizaram a rede naquela efeméride e circunstância, além das fotos propriamente ditas, foram montagens criadas por artistas de todo 0 mundo, com apropriações feitas sobre a foto, onde ele, então, aparecia em várias situações distantes da realidade que tornaram o caso mundialmente conhecido. Nestas apropriações, o garotinho aparece dormindo sobre uma cama confortável, deitado entre brinquedos, dentre outras inúmeras homenagensmontagens ${ }^{15}$, fazendo com que a sua história entrasse para os Trending Topics ${ }^{16}$ (TTs) mundiais

110 conceito de meme é aqui utilizado em referência a artefatos digitais (postagens, fotos, vídeos, animações, etc) amplamente difundidos, compartilhados de forma "viral" na internet.

12 Disponível em http://www.buzzfeed.com/ryanhatesthis/humanity-washed-ashore?bftw\&utm_term=.uf3oLWr0m\#.fezYb4A8q (Acesso em 26/10/2015).

13 Disponível em http://noticias.uol.com.br/ultimas-noticias/bbc/2015/09/03/a-historia-por-tras-da-foto-do-menino-sirio-quechocou-0-mundo.htm (Acesso em 26/10/2015).

14 Disponível em http://www.aljazeera.com/news/2015/09/images-don-change-europe-150902220504564.html (Acesso em 26/10/2015).

15 Disponível em http://www.dailymail.co.uk/news/article-3222829/Outpouring-grief-continues-images-Syrian-toddler-Aylan-Kurdis-dead-body-Turkey.html (Acesso em 26/10/2015).

16 0s Trending Topics ou TTs consistem no ranking da utilização das hashtags (que são marcações de assuntos precedidas pelo rastreador de conteúdos \#) no microblog Twitter nas postagens daquela rede. 
pelo uso da hashtag \#humanitywashedashore (ou \#naufragiodahumanidade, como adotada no Brasil), oficialmente utilizada para divulgar o movimento artístico mobilizado nestas apropriações.

Sensibilizados pela circunstância, ilustradores, fotógrafos, pintores, desenhistas e criadores em geral transformaram a foto em imagens menos "aflitivas", "de partir o coração", "agressivas", "fortes", movimento de apropriações que novamente foi noticiado e repercutido na cobertura dos veículos jornalísticos, o que o Daily Mail classificou como uma expressão da "efusão do sofrimento" pela morte da criança síria ${ }^{17}$, como que em uma tentativa de mudar a sua história, 0 seu destino, colocando-0 "in a better place"18, ainda que imaginária, fantasiosamente.

Nesta efusão ou extravasamento, percebido pelo derramamento das emoções na rede através da utilização das hashtags (supracitadas) do movimento, era comum ver tweets com pedidos de "misericórdia", "justiça" e "solidariedade" e indagações sobre "para onde caminha a humanidade?" ou outras como "cd [sic] esse deus que o povo tanto chama. porque [sic] nao [sic] faz nada". Em meio a estas manifestações de efusão sentimental, ganharam força também compartilhamentos sobre a notícia de que 0 casal de atores Angelina Jolie e Brad Pitt ${ }^{19}$ teria declarado interesse em adotar uma criança síria.

Hannah Arendt, em seus escritos de 1969, dizia explicitamente que "[o]nde todos somos culpados ninguém o é; as confissões de culpa coletiva são a maior salvaguarda possível contra a descoberta dos culpados" (ARENDT, 1994, p.48). Pode-se aferir que há no conjunto significativo das imagens apropriadas nos memes em homenagem ao menino sírio uma tentativa de ressignificar a tristeza de seu destino em vida, incrustando nessas apropriações releituras de outra possibilidade, a fim de nos absolver de culpas ou impotências - potências convertidas para dentro de nós, engolidas, introspectivas, não externalizadas em práticas de ação.

Estamos tirando proveito da capacidade comunicativa que os dispositivos que operamos têm, delegando a eles a tarefa de fazer "por nós", em nossas práticas cotidianas, a "verdadeira" mudança, o agir próprio do exercício ético? Como diria Baudrillard (1992), teríamos destinado nosso pensar às máquinas inteligentes, por cansaço ou incompetência? Assim como a Internet e suas redes facilitaram a aproximação das pessoas e dos grupos de interesse na prática ativista, fazendo com que novas vozes possam se expressar, essa

17 Disponivel em https://www.google.com.br/search?q=\%23HumanityWashedAshore\&biw=1366\&bih=667\&source=Inms\&tbm=isc h\&sa=X\&ved=0CAcQ_AUoAmoVChMI3YnZhI7eyAIVyIWQCh0pBwV0 (Acesso em 26/10/2015).

18 Disponível em https://scontent.cdninstagram.com/hphotos-xaf1/t51.2885-15/s640x640/sh0.08/e35/11849962_167032327317 9072_1352611309_n.jpg (Acesso em 26/10/2015).

19 Disponível em http://www.purepeople.com.br/noticia/angelina-jolie-e-brad-pitt-preparam-papeis-para-adocao-de-criancasiria_a77377/1 (Acesso em 26/10/2015). 
mesma possibilidade de expressão não poderia ser agora 0 calcanhar-de-aquiles de nossa potência de agir, dedicada agora apenas ao espelho da rede, e não a outras ações práticas do cotidiano? Essas ruidosas manifestações de indignação movimentadas mundo afora não seriam silenciadas e sanadas no nosso desabafo diário no muro de lamentações da rede digital?

A evocação do evento traumático (tal como 0 consumo da imagem de Alan, a imagem crua ou as apropriações suavizadas) movimenta a nossa paixão infeliz pelas imagens da violência, sensologia estetizante que passeia pendularmente entre o pânico moral e 0 gozo catártico. Qual é o nosso contrato de visibilidade com a imagem de Alan? Que lógica 0 ordena nesta poética "esterilizada" pelas técnicas midiáticas? Estamos vivendo eticamente ou, moralistas a tempo parcial, vivenciando exercícios de comoção soft?

Nosso modo de habitar e de fazer mundo responde à entrada em moradas simbólicas que utilizamos para lidar com as incertezas - a linguagem, as produções imagéticas, 0 universo imaginário, os sonhos, os ritos. Repugnar a foto de uma criança morta, não querer vê-la, ignorála, ou ainda apenas querer vê-la pelas vias de uma montagem mais amena de sua realidade (tal como ocorre com os memes) não seria um dos lados menos nobres de nossos afetos, 0 de não admitir ou querer encarar a realidade em que vivemos, que construímos em nosso dia a dia? Vivemos no consumo das imagens (e nas imagens de Alan) uma experiência sensorial circunscrita a uma narrativa terapêutica (ILLOUZ, 2011), de atravessamento dos males que nos cercam e sentimos?

0 afeto não é uma ação em si, mas é a energia interna que nos impele a agir, que confere um "clima" ou uma "coloração" particulares a um ato. Por isso, 0 afeto pode ser definido como o lado da ação que é "carregado de energia", no qual se entende que essa energia implica, simultaneamente, cognição, afeto, avaliação, motivação e 0 corpo. Longe de serem pré-sociais ou pré-culturais, os afetos são significados culturais e relações sociais inseparavelmente comprimidos, e é essa compreensão que thes confere sua capacidade de energizar a ação. 0 que faz 0 afeto transportar essa "energia" é 0 fato de ele sempre dizer respeito ao eu e à relação do eu com outros culturalmente situados (ILLOUZ, 2011, p. 09).

Se 0 homem padece de afetos como 0 ódio, 0 ciúme, a soberba, padece assim de excessos que podem incapacitá-lo de agir, deixando-o preso às suas paixões, tornando-o refém de suas próprias paixões. Nesta centralidade das visualidades na cena social e afetual da atualidade, não estaríamos submergindo em nossa incapacidade de agir "na prática", iludidos pela nossa ação representacional (na rede)? Qual é o sentido ético das postagens e publicações da imagem de Alan? Em que, efetivamente, sua veiculação ajuda a conscientizar, a mudar a situação da crise da imigração? A imagem de Alan torna-se um ícone, um totem, um ídolo post mortem cultuado na rede como ponto de expurgação dos males que nos afligem, do que nos afeta? 
0 excesso de imagens do menino sírio - um tipo de luto midiatizado, um luto da representação, e, por suposto, a evocação de um funeral da política representativa - nos custaria uma anestesia induzida (por esse excesso extrapolado de ver tais imagens) de ação, de potência de agir? Isso leva a pensar, em concordância com Jameson (1995), que a lógica visual é paradigmática das políticas de significação contemporâneas. Atualizando as derivações debordianas sobre a sociedade do espetáculo, a vida se atomiza e se banaliza em uma orquestra espetacular, em uma rede de compensações cuidadosamente agenciada.

Tomar a crítica da representação como método implica em "decupar" as visualidades para pensar a potência de agir, o nosso ser no mundo que é sujeito de coletividades. Podemos nos reconhecer sujeitos em relação a uma comunhão - uma "poética das convivialidades". É desta ética que falamos, uma utopia do consumo ético das imagens, que implica em civilizar a dita civilização das imagens, e "nem sempre agindo movidos pela paixão que nelas desejamos desejar" (AUTOR, 2010, p. 206).

Pensando no caso de Alan, não se firmaria na rede a construção de uma ideologia coletiva marcada pela construção imagética de um universo imaginário, afável, um "mundo do bem, de gente do bem"? Assim, como nota-se nas homenagens feitas nas apropriações artísticas da imagem de Alan, não estaríamos forjando um mundo melhor, onde as pessoas se importam efetivamente umas com as outras, para poder suportá-lo? Não estaríamos apenas regurgitando a nossa indignação no choro nas telas, enquanto nas práticas cotidianas nossa potência de agir permanece inerte, neutralizada, petrificada? 0 questionamento é relevante para ampliar as discussões sobre a formação e a mobilização de identidades coletivas na contemporaneidade e como as relações de consumo pautam essa formação.

Nesta dinâmica comunicacional, em que se perde a distinção entre emissor, canal e receptor, em um cenário em que todos produzem e - midiáticoantropofagicamente - consomem conteúdo, a comunicação expressiva - pelas tecnologias visuais, representacionais - pode se tornar uma máquina tautística (SFEZ, 1994; 2007). Isto resultaria em um tautismo (neologismo que une a tautologia e 0 autismo), 0 qual simula uma ilusão de ser e estar, em que a experiência mediada parece ser autêntica, fazendo-nos entrar em uma comunicação orgânica, de autofabricação de dados, autofágica. À sedução une-se a hipertelia, processo no qual a comunicação se desdobra através de uma rede giratória sem fim (e sem propósito), ampliando seu campo a cada volta. No cerne deste movimento ocorre também o que Sfez nomeia como sideração. 0 espectador torna-se mudo, quase autista, $\mathrm{e}$ acredita estar em contato com os outros em um grande todo sincrônico, ecossistêmico, até mesmo autogestionário. Contudo, entram em contato apenas consigo mesmos, em um autismo tautológico pelo qual se repete interminavelmente a mesma cerimônia abstrata, um autismo totalizante pelo qual somos diluídos no absoluto do mundo, 
por não termos conseguido nos separar dele para compreendê-lo (SFEZ, 1994; 2007).

Na cobertura da imprensa mundial, era também presente o recurso visual dos infográficos, publicados por todo o mundo em jornais e portais informativos, mostrando em um ponto marcado no mapa mundi a distância geográfica entre determinados países e o local onde ocorreu a morte de Alan. Além dessas infografias, muitos jornais referiam-se também a uma "crise europeia" ou "do litoral Mediterrâneo", como se os seus reflexos e circunstâncias tensas sobre imigração e preconceito racial não atingissem quem está geograficamente distante, como se a circunstância de infortúnio vivida por Alan fosse isolada, rara, localizada somente "naquela região", "lá", "longe".

Na origem do debate moderno que, longamente, tem oposto idólatras a textólatras, a estetização do cotidiano não é tão preocupante quanto a "estatistização" da estética. 0 exercício iconoclasta se faz necessário, e em duas direções. De um lado, como recurso de enfrentamento da tecnificação do olhar. De outro, como estratégia de reflexividade ante a hipersensologia midiática.

\section{Afetos, sensibilidade e políticas possíveis para 0 visivel}

Jean Baudrillard (1992), o mais ácido e irônico dos profetas do apocalipse, já nos anos 1990 não possuía mais ilusões, nem quanto à estética, para ele transfigurada em transestética, nem quanto à política, que percebia midiatizada, esfacelada, enterrada definitivamente sob os escombros do que chamou, em um de seus livros mais estupefatos, de "a greve dos acontecimentos". Baudrillard, que havia sido um dos primeiros e mais sensíveis defensores dos movimentos negros que tomaram de assalto os guetos e cidades norteamericanos nos anos 1970 (em uma "insurreição dos signos", como ele diria), talvez não tenha chegado a se impactar fortemente com os sons, vídeos e fotografias que, partindo das periferias parisienses, mobilizaram jovens imigrantes, levando-os, em um compartilhamento vertiginoso de mensagens em celulares baratos, a incendiar 0 berço da capital francesa, no início da década de 2000. Talvez ali não visse política, nem estética, mas apenas expressão de barbárie.

Como representar a miséria humana? Como encontrar os olhos para vê-la? Quais são os limites (éticos) possíveis para uma estética engajada na construção de um mundo do "nós", como propõe Michel Serres (2015)? Escrevendo sobre política e estética, Walter Benjamim (1986) talvez tenha sido o primeiro a auscultar de modo mais preciso os meandros desta ordem de relação, e, particularmente, para perceber como seria totalmente reconfigurada pela emergência da sociedade burguesa, tão ciosa de suas imagens quanto os nobres o eram de seus espelhos. Em um de seus textos mais disseminados (e, podemos dizer, mais banalizado), Benjamin (1986, p.196), crítico do fascismo e da emergência do espírito narcíseo-exibicionista-individualista, faz 0 alerta: 
ante a estetização da política, responde-se com a politização da estética.

Jacques Rancière (2006), leitor e crítico da impostura benjaminiana, é um dos pensadores contemporâneos que regressa às polêmicas atinentes a tais preocupações. Para Rancière (2006), sempre que falamos em partilhar algo - como o fizemos com as imagens do pequeno sírio -, dois movimentos estão ali implicados: 0 comungar e o distribuir, ou seja, uma determinada “divisão do sensível” (RANCIÈRE, 2006, p.7).

No novo paradigma estético proposto por Guattari (1993), sabemos que ele envolve uma análise corajosa das implicações e dos contornos das máquinas tecnológicas de informação e de comunicação àquelas que, segundo 0 autor, operam no núcleo da subjetividade humana. Para ele, estas implicações são simultaneamente homogeneizadoras, reducionistas e heterogenéticas, ou seja, elas significam cerceamento, mas igualmente acolhem a pluralidade. Ou seja, transpor a ideia da "partilha do sensível", cerne da política em Rancière, para pensarmos as narrativas e os imaginários do consumo midiático pressupõe a existência de instâncias comuns, de identidades sociais, de projetos coletivos sendo articulados por estas práticas de consumo.

Rancière (2006) analisa "atos estéticos como configurações da experiência, que ensejam novos modos de sentir e induzem novas formas de subjetividade política" (RANCIÈRE, 2006, p.11).
Em sua busca por um sensível que emancipa, nosso autor encontra a política como forma da experiência (sensível) e como uma questão de visibilidade e competência enunciativa.

Assim, falar de estética significa tocar frontalmente um debate que é a um só tempo artístico, sensível, ideológico e político, qual seja, o da ordem da representação, com seus aparelhos, com seus soldados e suas instituições, cujo controle, secularização e, posteriormente, paradoxal canonização foram elementos seminais na constituição e mundialização da moderna sociedade burguesa, a mesma que, curiosamente, ergue e destrói seus próprios ídolos, em uma mecânica pendular de celebrização e devoração, de idolatria e iconoclasmo.

Ao plano dos afetos, acresce-se 0 da política de representação, assim como a este se confronta, insubordinado e transgressor, o descomedimento humano, a porção demens do sapiens, a que nos permite imaginar, simbolizar, criar, gargalhar e, em essência, a que contempla os ódios e as destruições, mas igualmente enseja ao compartilhar, ao conviver, ao amar.

Unindo o político ao estético, tensiona-se a linha civilizatória, e poderemos agora examinar a correlação entre estética, política e subjetividade, ou, mais exato seria dizer, entre subjetividades e sensibilidades individuais e projetos coletivos, mesmo e talvez principalmente quando estas e estes fujam às normatividades programadas. 
Laclau (2008) é um daqueles que nos convoca a debater as identidades coletivas, insistindo que retomar a iniciativa política demanda, do ponto de vista teórico, fazer a política novamente pensável. Rancière (2009), por seu turno, desenvolve a ideia de uma "partilha do sensível" tecida pelas junções entre práticas políticas e práticas estéticas. Guattari (1993) propõe que a produção maquínica de subjetividade deve ser julgada a depender de como for sua articulação com os agenciamentos coletivos de enunciação. 0 novo paradigma estético é processual, "trabalha os paradigmas científicos e éticos e é por eles trabalhado (...) [e] tem implicações ético-políticas porque quem fala em criação, fala em responsabilidade da instância criadora em relação à coisa criada" (GUATTARI, 1993, p.136).

Ora, se são inegáveis, múltiplas e profundas as mudanças estéticas e da sensibilidade articuladas às novas lógicas de produção e consumo de midialidades, mundialidades e tecnicidades, nem sempre tais alterações se fazem acompanhar de similar "desenvolvimento" humano, nem, menos ainda, garantem, de per si, a concepção e consecução de projetos humanistas. Nas sedutoras sociedades do pós-espetáculo, da dromocracia (Cf. VIRILI0) e da visibilidade máxima, o primeiro grande enfrentamento é no âmbito da promoção de nossa competência ética.

À gramatura espetacular do excesso - excesso de informações, excesso de mobilizações sensórias, excesso de demandas cognitivas
-, as subjetividades possíveis implicam a problematização da multiplicidade compulsória gestada pela fragmentação e pela fluidez. A flexibilidade, neste caso, nem sempre conduz a uma mobilidade eticamente fundada. Abandonar a rigidez, de um lado. Desconfiar da fragmentação excessiva, de outro (ROCHA, 2012), é um de nossos remédios.

É Rancière (2009) quem nos acompanha no encerramento desta escrita. Para nosso autor, retomando a ideia lyotardiana da estética como lugar do luto (luto do pensamento crítico), seria ainda possível reestabelecermos as condições de inteligibilidade do debate, este que se pergunta "o que é a estética?", mas que também pode indagar "o que é a política?". Rancière, com sua compreensão cênica do fazer político e coreográfica da comunidade, com sua apreensão da política como forma de experiência do sensível, talvez seja um dos mais potentes analistas do contemporâneo que beneficiam 0 debate comunicacional acerca do que aqui nomeamos uma ética para as visualidades. Isto porque Rancière permite-nos analisar as narrativas midiáticas como efetivamente sendo superfícies de "partilha do sensível", as quais propõem relações bastante diversas entre 0 dizível e 0 visível.

Direcionando sua escuta para 0 significado do "anônimo" na arte, 0 autor nos apresenta a grande inversão dos últimos tempos, verdadeira ruptura no edifício da representação clássica provocada pela ascensão deste "qualquer um". 
Desenvolvendo esta ordem de raciocínio, Rancière nos aponta, com clareza ímpar, o que entende ser 0 valor do banal como pista do verdadeiro. É nesta direção que a ficção, como arte narrativa, teria efeitos reais, definindo "regimes de intensidade sensível" e coletivos de enunciação. Nesta "nova maneira de contar histórias", dá-se sentido "ao universo 'empírico' das ações obscuras e dos objetos banais" (RANCIÈRE, 2009, p.55).

Se "[a] política e a arte, tanto quanto os saberes, constroem 'ficções'” (RANCIÈRE, 2009, p.59), talvez a ética do visível construa horizontes de partilha humanista, reconduzindo os videntes não a uma condição especial de espectorialidade, mas, antes, ao plano mais banal de sua existência. Este mesmo que nos faz, logo aqui, próximos demais de tantos longes daqui. E é nesta condição de banal humanidade que talvez possamos encontrar os olhos pra ver. E as condições políticas e estéticas de, inclusive, decidir sobre nosso horizonte de consumo e produção de representações. No solo energizado das superfícies midiáticas, 0 cadáver de Alan evoca a mortalidade dos corpos que 0 visibilizam, mas, igualmente, denuncia a materialidade sombria que conduziu o destino terrível de seu breve existir. 0 cadáver de Alan revela a obscuridade de todo um sistema.

\section{Referências}

ARENDT, Hanna. Sobre a violência. Rio de Janeiro: Relume-Dumará, 1994.

BAUDRILLARD, Jean. A transparência do mal. Campinas: Papirus, 1992.
BENJAMIN, Walter. Magia e técnica, arte e política. São Paulo: Brasiliense, 1994.

CARDOSO, Sérgio. 0 olhar do viajante. In: NOVAES, Adauto. 0 olhar. São Paulo: Companhia das Letras, 1993.

CASTELLS, Manuel. A galáxia da Internet: reflexões sobre a internet, os negócios e a sociedade. Rio de Janeiro: Jorge Zahar, 2003.

GUATTARI, Félix. Caosmose. Rio de Janeiro: Ed. 34, 1993.

ILLOUZ, Eva. 0 amor nos tempos do capitalismo. Rio de Janeiro: Zahar, 2011.

JAMESON, Fredric. As marcas do visível. Rio de Janeiro: Graal, 1995.

LACLAU, Ernesto. Debates y combates. Por un nuevo horizonte de la política. Buenos Aires: Fondo de Cultura, 2008.

LIESENBERG, Susan. Humor e ativismo político: práticas de cidadania e consumo pós-periférico na comunicação. In: Trabalho apresentado no Grupo de Trabalho Comunicação, Consumo e Novos Fluxos Políticos: Ativismos, Cosmopolitismos, Práticas Contrahegemônicas (GT5), do $5^{\circ}$ Encontro de GTs Comunicon, São Paulo: COMUNICON, 2015. Disponível em http://anais-comunicon2015.espm.br/GTs/GT5/12_GT_05_ LIESENBERG.pdf Acesso em 10/12/2015.

PRIMO, Alex. Interney Blogs como micromídia digital: Elementos para 0 estudo do encadeamento midiático. In: $17^{\circ}$ Encontro Anual da Associação Nacional dos Programas de Pós-Graduação em Comunicação, 17, 2008, São Paulo. Anais... São Paulo: COMPÓS, 2008. P.1-17. Disponível em http://www.ufrgs.br/limc/PDFs/ interney.pdf. Acesso em 28/10/2015.

RANCIÈRE, Jacques. A partilha do sensível. Rio de Janeiro: Ed. 34, 2009.

RINCÓN, Omar. Narrativas mediáticas. 0 cómo se cuenta la sociedad del entretenimiento, col. Estudios de televisión, núm. 23. Barcelona: Gedisa, 2006. 
ROCHA, Rose de Melo. Culturas juvenis, consumo e politicidades: uma abordagem comunicacional. In: SAMPAIO, Inês (org.). Comunicação, cultura e cidadania.Campinas: Pontes Editores, 2012 . Políticas de visibilidade como fatos de afecção: Que ética para as visualidades?. Revista FAMECOS. Porto Alegre, v. 17, n. 3, p. 199-206. setembro/dezembro 2010.

RODRÍGUEZ, Ana. Iconofilia y prácticas artísticas.

ICONOS. Quito, N.20, Flacso-Ecuador, p. 90-95, 2004.

SERRES, Michel. Narrativas do humanismo.

Rio de Janeiro: Bertrand Brasil, 2015.

SFEZ, Lucien. A Comunicação. São Paulo:

Martins Fontes, 2007.

. Crítica da comunicação. São Paulo:

Edições Loyola, 1994.

SPINOZA, Baruch. Ética. Belo Horizonte:

Autêntica, 2008.

VIRILIO, Paul. 0 espaço crítico. Rio de Janeiro: Ed. 34, 1993. 


\section{The sensitive eye: (aesth)ethics of visible and visibility policies}

\section{Abstract}

By analysing the path of mediatization and energization that surfaced around the consumption of Alan Kurdi's picture, syrian kid who died in 2015 during a frustrated attempt of immigration, the problems of sharing the sensible and the ethical implications of this kind of visibility come around. By considering the critics of the visible as an indagation method, it advocates that the result of this kind of mediatic exposure is paradoxical and ambivalent. The consumption and desecration of the victim's image, on which its undeniable power of denunciation weights, can also contribute for a mediatic sensibilization cycle that immobilizes its receivers, offering them "indignation pills". We conclude with a question: couldn't the pedagogical dimension of image consumption implicate on an aesthetic policy less immediatist and individualist?

\section{Keywords}

Visibility policies. Ethics of the visible. Sharing of the sensitive. Alan Kurdi. Mediatic consumption

\section{El ojo sensible: (est)ética de lo visible y políticas de visibilidad}

\section{Resumen}

Analizando el circuito de mediatización y energización que gravitó alrededor del consumo de la imagen de Alan Kurdi, niño sirio muerto en 2015 durante el intento fallido de la inmigración, hablamos de "distribución de lo sensible " y sobre las implicaciones éticas de este tipo de visibilidad. Tomando la crítica del visible como método de investigación, se argumenta que resulta paradójico y ambivalente este tipo de exposición mediática. El consumo y la profanación de la imagen de la víctima, a pesar de su potencial innegable, también puede contribuir a un ciclo de sensibilización que inmoviliza sus receptores, ofreciéndoles "píldoras de indignación”. Se concluye también con una pregunta: la dimensión pedagógica del consumo de imágenes no podría dar lugar a una política de la estética menos inmediatista y individualista?

\section{Palabras clave}

Politicas de visibilidad. Etica de lo visible. Distribución de lo sensible. Alan Kurdi. Consumo mediático. 


\section{Expediente}

A revista E-Compós é a publicação científica em formato eletrônico da Associação Nacional dos Programas de Pós-Graduação em Comunicação (Compós). Lançada em 2004, tem como principal finalidade difundir a produção acadêmica de pesquisadores da área de Comunicação, inseridos em instituições do Brasil e do exterior.

\section{E-COMPÓS I www.e-compos.org.br I E-ISSN 1808-2599}

Revista da Associação Nacional dos Programas de Pós-Graduação em Comunicação.

Brasília, v.18, n.3, set./dez. 2015.

A identificação das edições, a partir de 2008, passa a ser volume anual com três números.

Indexada por Latindex I www.latindex.unam.mx

\section{CONSELHO EDITORIAL}

Alexandre Farbiarz, Universidade Federal Fluminense, Brasil Alexandre Rocha da Silva, Universidade Federal do Rio Grande do Sul, Brasil Ana Carolina Damboriarena Escosteguy, Pontifícia Universidade Católica do Rio Grande do Sul, Brasil

Ana Carolina Rocha Pessôa Temer, Universidade Federal de Goiás, Brasil Ana Regina Barros Rego Leal, Universidade Federal do Piauí, Brasil Andrea França, Pontifícia Universidade Católica do Rio de Janeiro, Brasil André Luiz Martins Lemos, Universidade Federal da Bahia, Brasil Antonio Carlos Hohlfeldt, Pontifícia Universidade Católica do Rio Grande do Sul, Brasil

Arthur Ituassu, Pontifícia Universidade Católica do Rio de Janeiro, Brasil Álvaro Larangeira, Universidade Tuiuti do Paraná, Brasil Ângela Freire Prysthon, Universidade Federal de Pernambuco, Brasil César Geraldo Guimarães, Universidade Federal de Minas Gerais, Brasil Cláudio Novaes Pinto Coelho, Faculdade Cásper Líbero, Brasil Daisi Irmgard Vogel, Universidade Federal de Santa Catarina, Brasil Denize Correa Araujo, Universidade Tuiuti do Paraná, Brasil Eduardo Antonio de Jesus, Pontifícia Universidade Católica de Minas Gerais, Brasil

Daniela Zanetti, Universidade Federal do Espirito Santo, Brasil Eduardo Vicente, Universidade de São Paulo, Brasil Elizabeth Moraes Gonçalves, Universidade Metodista de São Paulo, Brasil Erick Felinto de Oliveira, Universidade do Estado do Rio de Janeiro, Brasil Francisco Elinaldo Teixeira, Universidade Estadual de Campinas, Brasil Francisco Paulo Jamil Almeida Marques, Universidade Federal do Paraná, Brasil

Gabriela Reinaldo, Universidade Federal do Ceará, Brasil Goiamérico Felício Carneiro Santos, Universidade Federal de Goiás, Brasil Gustavo Daudt Fischer, Universidade do Vale do Rio dos Sinos, Brasil Herom Vargas, Universidade Municipal de São Caetano do Sul, Brasil Itania Maria Mota Gomes, Universidade Federal da Bahia, Brasil
Janice Caiafa, Universidade Federal do Rio de Janeiro, Brasil Jiani Adriana Bonin, Universidade do Vale do Rio dos Sinos, Brasil José Afonso da Silva Junior, Universidade Federal de Pernambuco, Brasil José Luiz Aidar Prado, Pontifícia Universidade Católica de São Paulo, Brasil Juçara Gorski Brittes, Universidade Federal de Ouro Preto, Brasil Kati Caetano, Universidade Tuiuti do Paraná, Brasil

Lilian Cristina Monteiro França, Universidade Federal de Sergipe, Brasil Liziane Soares Guazina, Universidade de Brasília, Brasil Luíza Mônica Assis da Silva, Universidade de Caxias do Sul, Brasil Luciana Miranda Costa, Universidade Federal do Pará, Brasil Malena Segura Contrera, Universidade Paulista, Brasil Maria Ogécia Drigo, Universidade de Sorocaba, Brasil Maria Ataide Malcher, Universidade Federal do Pará, Brasil Marcia Tondato, Escola Superior de Propaganda e Marketing, Brasil Marcel Vieira Barreto Silva, Universidade Federal da Paraíba, Brasil Maria Clotilde Perez Rodrigues, Universidade de São Paulo, Brasil Maria das Graças Pinto Coelho, Universidade Federal do Rio Grande do Norte, Brasil

Mauricio Ribeiro da Silva, Universidade Paulista, Brasil

Mauro de Souza Ventura, Universidade Estadual Paulista, Brasil Márcio Souza Gonçalves, Universidade do Estado do Rio de Janeiro, Brasil Micael Maiolino Herschmann, Universidade Federal do Rio de Janeiro, Brasil Mirna Feitoza Pereira, Universidade Federal do Amazonas, Brasil Nísia Martins Rosario, Universidade Federal do Rio Grande do Sul, Brasil Potiguara Mendes Silveira Jr, Universidade Federal de Juiz de Fora, Brasil Regiane Regina Ribeiro, Universidade Federal do Paraná, Brasil Rogério Ferraraz, Universidade Anhembi Morumbi, Brasil Rose Melo Rocha, Escola Superior de Propaganda e Marketing, Brasil Rozinaldo Antonio Miani, Universidade Estadual de Londrina, Brasil Sérgio Luiz Gadini, Universidade Estadual de Ponta Grossa, Brasil Simone Maria Andrade Pereira de Sá, Universidade Federal Fluminense, Brasil Veneza Mayora Ronsini, Universidade Federal de Santa Maria, Brasil Walmir Albuquerque Barbosa, Universidade Federal do Amazonas, Brasil

\section{COMISSÃO EDITORIAL}

Cristiane Freitas Gutfreind

Pontifícia Universidade Católica do Rio Grande do Sul, Brasil

Irene Machado

Universidade de São Paulo, Brasil

\section{CONSULTORES AD HOC}

Claudia Peixoto de Moura, Pontificia Universidade Católica do Rio Grande do Sul, Brasil Francisco Rüdiger, Pontifícia Universidade Católica do Rio Grande do Sul, Brasil Juremir Machado da Silva, Pontifícia Universidade Católica do Rio Grande do Sul, Brasil Maria Aparecida Baccega, Universidade de São Paulo, Brasil

Roberto Tietzmann, Pontifícia Universidade Católica do Rio Grande do Sul, Brasil

\section{EQUIPE TÉCNICA}

ASSISTENTE EDITORIAL I Márcio Zanetti Negrini

REVISÃO DE TEXTOS I Press Revisão

EDITORAÇÃO ELETRÔNICA I Roka Estúdio

CONTATO I revistaecompos@gmail.com
COMPÓS I www.compos.org.br

Associação Nacional dos Programas de Pós-Graduação em Comunicação

Presidente

Edson Fernando Dalmonte

Programa de Pós-Graduação em Comunicação

e Cultura Contemporânea - UFBA

edsondalmonte@uol.com.br

Vice-presidente

Cristiane Freitas Gutfreind

Programa de Pós-Graduação em Comunicação Social - PUC-RS cristianefreitas@pucrs.br

Secretário-Geral

Rogério Ferraraz

Programa de Pós-Graduação em Comunicação

Universidade Anhembi Morumbi

rogerioferraraz@anhembimorumbi.edu.br 